\title{
A Study on Measures to Prevent Water Eutrophication in Longhu Lake, Jinjiang
}

Liandeng Zeng ${ }^{1, \text { a }}$

${ }^{1}$ Water conservancy bureau of Jinjiang, 362200, China

aemail: 183863178@qq.com

Keywords: Water Eutrophication; Endogenous pollution; Water quality; pollution processing project

\begin{abstract}
As the biggest natural freshwater lake in Jinjiang, Longhu Lake now serves the drinking water source for four towns in South Shanxi Province and Jinmen. The paper evaluates the state of nutrition of Longhu Lake on the basis of analyzing the status quo of Longhu Lake, and proposes seven measures to prevent from reservoir eutrophication, including sewage interception and pipe layout, disposal of inbound rivers, vegetation buffer belt surrounding the lake, processing of endogenous pollution, construction of inbound wetland, biomanipulation and water quality monitoring. Through system engineering and non-engineering processing, enhancing control on pollution source and protecting ecological environment, we aim to protect the drinking water source.
\end{abstract}

\section{Introduction}

Water eutrophication refers that $\mathrm{N}, \mathrm{P}$ and other nutrients flood into water so that algae and other planktons proliferate vigorously, which thus damages the ecological balance of water and deprives water of original values. "Eutrophication" is a water pollution phenomenon caused by excessiveness of plant nutrients, such as $\mathrm{N}, \mathrm{P}$ and so on.

The studies on water eutrofication and pollution prevention were carried out in Europe at the end of the 19th century. In the early time, the researches mostly focused on the water. However, due to the eutrofication and pollution was often closely related to water quality in basins, the studies related to the improvement of water quality correspondingly extended to the basin scale. At current, there is a prevailing awareness that only comprehensive management based on basin scale can play a fundamental role in preventing from water eutrophication and pollution. Domestic studies on water eutrophication and pollution prevention started at a late time. Depsite this, the studies in recent several decades have also made ooutstanding acheivements. The researches on water eutrophication and pollution prevention mainly concentrate on pollution control management mechanism and pollution control technology.

At present, the disposal of water eutrophication is mainly carried out from two perspectives: First, control the input of exogenous nutrients, such as sewage interception \& diversion and centralized sewage processing. It is mainly used for controlling point source pollution. Second, reduce the load of endogenous nutrients, such as microbial remediation, sediment dredging, chemical method, constructed wetlands, restoration of aquatic vegetation, etc. The purpose is to control non-point source pollution and accelerate the restoration of lakes and reservoirs [1-2]. According to the current technological conditions, point source pollution can be well handled by sewage interception and central sewage management. Endogenous pollution and non-point source pollution are the two major difficulties in controlling resevoirs' eutrophication. This is also the research focus on water in recent years [3-6].

Jinjiang is located in southeast coast in Fujian, southern coast of the lower stream of Jinjiang, and adjacent to seas on three sides. It is one of the most economically developed counties in China. Longhu Lake is situated in Longhu Town, southern part of Jinjiang, located in Hulou Basin. The water-collecting coverage is $11 \mathrm{~km} 2$ and the lake surface area is $1.6 \mathrm{~km} 2$. It is the terminal of water supply network in Jinjiang. The runoff from Jinjizha Reservoir, Jinjiang is $4.4 \mathrm{~m} 3 / \mathrm{s}$, which serves as the source of drinkable water for Longhu Lake, Yinglin, Jinjing, Shenhu and Jinmen. 
At current, the water in Longhu Lake mainly originates from external basins. The water quality abides by Standard II in "Standard on Environmental Quality of Surface Water". The current water quality, except total phosphorous all conforms to Standard II. According to the analysis of quality of exogenous water in Longhu Lake, the main source of excessive amount of total phosphorus is total phosphorous pollution. Within the range of Longhu Lake, due to a large number of villages, domestic sewage is directly discharged to surrounding lake and sewage intercepting trench without processing. As a result, the water in the sewage intercepting trench is black and filthy. During rainfall seasons, there are certain effects on the quality in Longhu Lake. Since the establishment, Longhu Lake has not been dredged for many years. There are a lot of deposit at the bottom of rivers. Hence, it is urgent to systematically facilitate the preservation of Longhu Lake, improve the water quality in Longhu Lake and prevent from eutrophication so as to ensure the security of drinkable water supply in four towns in South Jinjiang and Jinmen as well.

\section{Overall plan of preventing from eutrophication in Longhu Lake}

(1) Sewage interception and decontamination duct project

In general, pollution processing is carried out from the source. Sewage interception and renovation is conducted on the sewage source, i.e., intercepting the domestic sewage from residents along the river. However, because sewage interception and renovation cannot be completed during a short period of time, it is a process of implementation. Hence, besides carrying out holistic interception of sewage in the surrounding areas in a long term, the measures of improving water environment surrounding Longhu Lake should also be taken. In the near term, the rectification of domestic sewage and industrial waste water should be attached great importance to. A complete sewage collection and processing system should be set up. For the surrounding newly constructed areas, combining with the construction of the areas, rainfall and sewage should be intercepted. In order to improve the water quality in the intercepting sewage trench in the surrounding reservoir at present, the sewage along the rivers should be gathered to the discharging point. In the well-equipped areas along the rivers, set up wetland system or vegetation buffer zone as well as other ecological measures so as to relieve the effects of surrounding domestic sewage and industrial waste water on the reservoir zone.

(2) In-reservoir river pollution processing project

Non-point source pollution has become the biggest pollution source in the water environment. In multiple in-reservoir pollution channels, in-reservoir rivers are the "throat" of the reservoir. Many pollutants flow into the reservoir from the in-reservoir watercourses. After gathered by the surface runoff, in-reservoir rivers can carry various residents' domestic sewage, breeding waste water, fertilizers, pesticides, rubbish and other pollutants remained in the soil surrounding the reservoir and other pollutants to form in-reservoir pollution.

In order to better control external contamination, protect the water in Longhu Lake, improve the conditions of water quality in the intercepting sewage trench in Longhu Lake, waterway wetland project is established in external drainage in Longhu Lake. Waterway artificial wetland is the partial rectification and renovation of current rivers, by expanding partial bottomland on the two sides of the waterway to a certain degree, setting up waterway artificial wetland processing system, making use of the changes of waterway's natural river level and water's flowing by artificial wetland to reach the purpose of sewage processing. Because of the seasonal changes of natural river's water level, the internal dry-and-wet alternate environment inside the wetland is thus created, which can better restore the substance properties of wetland substrates, enhance the wetland system's absorption of pollutants, and mow the plants on the wetland.

At present, the waterway's width ranges from $1 \mathrm{~m}$ to $4 \mathrm{~m}$. By taking advantage of the bottomland on the two sides of the waterway and some farmland, construct plan oxidation pond. In order to improve the purification efficiency of plant oxidation pond, construct the diverse ecological habitats whose water depth ranges from $50 \mathrm{~cm}$ to $200 \mathrm{~cm}$. According to different water depths, equip the pond with appropriate emerging, floating leaf and sinking vegetation to form the zones with different dissolved oxygen contents so as to help with the full degradation and absorption of $\mathrm{N}$ and 
P.

On the peripheral of the plant oxidation pond, plant emerging plants. By means of the density of plants, reach the purpose of guiding water flow so that the flow-in water in the upper stream of waterway can evenly enter the wetland. The original waterway zone is not changed topographically. Restore emerging vegetation. Dig deep to the original waterway on the two sides and form the zone that is $2 \mathrm{~m}$ in depth. Plant floating leaves and sinking plants and extend to the shore through the gentle slope with the sloping rate about 1:5.

(3) Vegetation buffer belt construction surrounding the lake project

Binshui Vegetation Buffer Belt is a stripe-shaped biological group with plants as the main components on the two sides of the waterway. The major role is to stabilize the bank, enrich biological diversity, beautify the scenery and reduce the number of pollutants that enter the waterway by means of filtering, decomposing and absorbing the pollutants. The land surrounding Longhu Lake is quite flat, which is suitable for the layout of vegetation buffer belt. Because surrounding Longhu Lake has constructed the sewage intercepting trench, the buffer belt should be laid outside the trench. The main function is to get rid of nutrients and control mud and sand. The minimal width should range from $10 \mathrm{~m}$ to $90 \mathrm{~m}$. According to the functions of vegetation buffer belt in surrounding Longhu Lake, on the basis of the status quo of surrounding village and road, buffer belt can be divided into three parts from the external to internal part: 1) Hedge belt: It is located in the outermost part of the buffer belt and composed of densest shrubs for intercepting the connection between the outside and Longhu Lake, and reducing the effects of surrounding production and living on Longhu Lake. 2) Arbor belt: Arbor belt is the major component of the buffer belt with the widest plantation range. It is located in the internal part of hedge belt and constructed through planting various adaptable arbors, and sowing brush in the forest. 3) Shrub belt: It is located in the internal part of arbor belt and connected with intercepting sewage trench as well as serves as the transitional belt between Longhu Lake and arbor belt. From the external to the internal part, it can be divided into large shrub belt, vegetation belt and herb belt specifically. In particular, vegetation belt is mainly distributed in village, road corner and the areas with high requirements on landscape.

(4) Endogenous pollution processing project

After point source pollution and non-point source pollution of reservoir are effectively controlled, endogeneous pollution becomes the focus in reservoir pollution processing as well as the difficult point in disposal. Under the intereaction of biology, chemistry and physics, the deposit substances transform and migrate in between the layer of mud and water, pollute the substances and thus impose severe threats on the upper-layered water bodies. In the reservoirs with a lower degree of eutrophication, the phenomenon is less obvious, while it is more obvious in those with a higher degree of eutrophication.

Reservoir dredging methods can be classified into non-water zone and inundated zone. Under the non-water condition, excavation method is mainly deployed in dredging. The equipment is simple, so is the operation method. In general, it does not affect the water quality. Neverthless, there are a lot of problems, including short dredging time, limted dredging range, a small amount of dredging, high engineering pricing and unobvious effects. Antoher method is pump-absorption dredging under the condition of water storage, which does not affect the normal operation of reservoir and exertion of functions. Long-term dredging can be carried out with a large dredging amount. In addition, the dredged items can be easily handled. The engineering pricing is relatively low with obvious effects. However, water quality protection should be attached importance to. Longhu Lake is the source of drinkage water for four towns in South Jinjiang. In order to ensure the normal water supply of Longhu Lake during the engineering period, after full considerations, the dredging selects pneumatic pump dredger to launch construction zone by zone. Before dredging, establish cofferdam to prevent from second pollution. In terms of the dredged sludge, it is suggested that it serve as the soil for sea filling constructio after processing.

(5) In-reservoir wetland construction project

In order to better protect the water quality in Longhu Lake and reduce the polluting loads entering the lake, set up In-lake Wetland Purification Project in the water-to-lake zone, carry out 
pre-processing of the water flowing into Longhu Lake by ecological means. On the one hand, in-lake wetland can slow down water flow, deposit sand and mud, and eliminate nutritious substances and pollutants in the form of particles. On the other hand, by setting up a positive in-lake ecological system, by making use of the decomposition and absorption function of plants and microorganism, get rid of the polluting substances in the in-water and bottom mud to improve the water quality. In-lake wetland ecological system generally includes along-shore wetland plant belt, floating plant belt, sinking plant belt, benthonic animal belt and so on. Sinking plant belt, floating plant belt and off-shore emerging plant belt are laid in the project.

(6) Biological manipulation project

Because the ecological system's structure and functions are not complte, certain biological manipulation measures are needed in restoration. Make use of trophic-level chain effect, change the food net chain structure by manual manipulation so as to reach the purpose of improving and restoring the ecological system's structure. Use the downward effect generated by trophic-level relationship among canivorous fishes - filter-feeding fishes - algae - nutritious substances, and try to get an advantageous response through re-constructing a biological group so as to reduce the quantity of algae, control N, P and other pollutants, declien the polluting loads on water, enhance rivers' reoxygenation ability, keep the clarity of water and improve biological diversity. At the same time, breed anodonta, snails and so on in water. Mussels can filter-feed the floating algae in water and organic detritus, and improve lake's tranparency, while snails mainly feed on fixed algae, and secrete substances facilitating flocculation so that floating substances can flocculate and purify the water.

(7) Ecological dispatch

At the beginning, reservoir dispatch method is mainly anti-flood dispatch and dispatch for beneficial purpose. From the perspective of protecting the ecological system, no ecological factorsa re involved. Water quality dispatch is a type of ecological dispatch to prevent from or relieve emergency pollution accidents, water eutrophication and algae bloom. For the sake of prevneting from water eutrophication, by changing the reservoir's dispatch operation method, reduce the water level during a certain period, increase the velocity of water so as to destroy the conditions of water eutrophication. During a certain period, increase the reservoir's runoff and supply amount during a certain period, enhance water circulation and disturbance density in the resevoir, and expand the content gradient at the level fo deposit substance, thus increasing the amount of release of endegenous pollutants, help with the disposal of endegenous pollutants in the resevoir, and slow down eutrophication.

(8) Water quality monitoring

As the source of drinkable water for South Jinjiang and Jinmen, water quality is correlated to the masses' benefits. On the one hand, it is necessary for Department of Water Supply and Water Origin Management to know the water quality in Longhu Lake so as to take emergency actions when water deteriorates, improve the pre-warning and quick responses to water pollution accident. On the other hand, the audience have the right to know the quality of the drinkable water origin, enhance the supervision on safe operation of water, and improve the passion in taking part in the protection of water origin. Besides, things of net water on-line monitoring system with intelligent water-quality sensor, wireless sensor network and expert database as the core is constructed. By distributed dynamic network, wide-range and 24h consecutive monitoring can be realized so as to improve management efficiency and ensure the safety of water supply.

\section{Conclusion and suggestions on the rationality of engineering design}

(1) Control pollution from the source is the key in water origin protection.

The villages surrounding Longhu Lake are densely distributed and under heavy loads of domestic sewage. In terms of engineering actions, pertinent to different pollution sources, considering the current situation and planning related to the surrounding area, take multiple actions, including sewage interception and decontamination duct, on-site processing, comprehensive disposal of upper-stream waterway. In terms of management measures, strictly abide by the 
regulations related to the management of water origin protection zone. It is suggested that water origin protection zone management be enhanced according to the different requirements on level-1 and level-2 drinkable water source protection zone, eliminate point source pollution, guide and restrict scientific water and fertilizer application in surrounding farmland.

(2) Ecologicalize the measures of engineering design

The project tries to improve water ecological system's structure in Longhu Lake. As a water origin protection place, relevant design plans should also consider whether the construction will have negative effects on water quality besides satisfying the technical requirements. Thus, the plan should be selected after the comparison of numerous design plans.

(3) Improve the quality of water environment and water ecology synchronously

On the one hand, the project needs to purify and improve water quality in Longhu Lake. On the other hand, it needs to restore the water ecological system. The wetland processing should choose natural wetland restoration plan as much as possible. Water should be purified by the plants and organism in plant habitats. What more, through plant and aquatic animal dispatch, the water ecological system's structure and functions can be perfected.

\section{References}

[1] Nixon, S.W. Coastal marine eutrophication: a definition, sicial causes, and future concerns[J]. Ophelia, 1995, 41: 199-219.

[2] DAVID H. Eutrophication of fresh water-principles, problems and restoration[M]. London: Chaman \& Hall, 1992.

[3] Moog O., Kloiber A. S., Thomas O. Does the ecoregion approach support the typological demands of the EU 'Water Frame Directive’?[J]. Hydrobiologia, 2004, 516: 21-33.

[4] J. D. Westervelt, Simulation modeling for watershed management, Springer, New York 2001.

[5] An S.Q., Li H., Guan,B. H. Zhou C. F. et al., China's natural wetlands: past problems, current status, and future challenges[J]. Ambio, 2007, 36 (4): 335-342.

[6] Frissell C. A., Liss W. J., Warren C. E., Hurley M. D. A hierarchical framework for stream habitat classification: viewing streams in a watershed context[J]. Environ. Manage, 1986, 10(2): 199-214. 